\title{
The Policy or the Person? A Corpus-based functional Analysis of Manifestos of two Political
} Parties in Ghana

\author{
Kwabena Sarfo Sarfo-Kantankah \\ Abstract
}

Containing the set of policies that political parties stand for and wish to implement if they are elected to govern a country, manifestos are a campaign tool used by political parties to persuade the citizenry to vote in a certain direction. This paper uses corpus-linguistic methods to investigate the key concepts in the manifestos of two Ghanaian political parties, namely: the New Patriotic Party (NPP) and the National democratic Congress (NDC). The objective is to examine the strategies and the focus of the manifestos of the two parties. The analysis reveals that while the NPP target both policy and the personalities of their opponent candidates, the NDC appear to focus mainly on policy. The paper concludes that, be it a focus on policy or personality, contextual relevance is the key. Thus, the paper proposes a relevance model of political campaign discourse. The paper has implications for political discourse, political campaigning and political communication.

Keywords: policy, person, corpus-based study, functional theory, manifestos

\section{Résumé}

Contenant l'ensemble des politiques que les partis politiques défendent et souhaitent mettre en œuvre s'ils sont élus pour gouverner un pays, les manifestes sont un outil de campagne utilisé par les partis politiques pour persuader les citoyens de voter dans une certaine direction. Cet article se sert des méthodes appartenant à la linguistique de corpus pour étudier les concepts clés dans les manifestes de deux partis politiques ghanéens, à savoir : Le New Patriotic Party (NPP) et le National Democratic Congress (NDC). L'objectif est d'examiner les stratégies et l'orientation des manifestes des deux partis. L'analyse révèle que si le NPP cible à la fois la politique et les personnalités des candidats de l'opposition, le NDC semble se concentrer principalement sur la politique. L'article conclut que, qu'il s'agisse de se concentrer sur la politique ou la personnalité, la pertinence contextuelle est la clé. Ainsi, l'article propose un modèle de pertinence du discours des campagnes politiques et comporte des implications pour le discours politique, les campagnes politiques et la communication politique.

Mots clés: politique, personne, étude basée sur un corpus, théorie fonctionnelle, manifestes

https://dx.doi.org/10.4314/contjas.v8i2.5

Kwabena Sarfo Sarfo-Kantankah (esarfo@ucc.edu.gh) is Associate Professor of English language in the Department of English, University of Cape Coast, Ghana. He obtained his PhD from the School of English, University of Leeds, UK, where he studied on Leeds International Research Scholarship. His PhD research focused on UK and Ghanaian parliamentary discourse. His research interests include corpus linguistics, discourse analysis, political discourse, parliamentary discourse and pragmatics. He has previously published in journals such as Language, Discourse \& Society; International Journal of Social Sciences and Education; African Nebula; Legon Journal of the Humanities, Corpora and Word. 


\section{Introduction}

Manifestos are essential in party politics and governance, as they reflect political parties' philosophies and ideologies. They affect policy formulation, communication and implementation and serve as a guide for the campaign strategies of political parties. As a yardstick, manifestos allow governments, leaders and the citizenry to gauge and question the direction in which parties want to take a country as well as measure the performance of governments. Eder, Jenny and Müller (2017: 83) have outlined three functions of electoral manifestos, namely:

i. “They collect a party's policy positions in one place for easy reference".

ii. they streamline the campaign by “defining and framing the party's key campaign themes and containing the populist impulses of factions or individual candidates who opportunistically might want to take a different stance on issues".

iii. manifestos can be used as campaign means to be handed out to voters. Even though manifestos may have no particular importance and can be seen as a compulsory exercise, it is a recurring ritualistic element of electoral campaigns.

Whereas research has concentrated more on the content of political party manifestos, less attention has been paid to how they are written (Eder et al., 2017). The current paper aims to identify the focal points of the manifestos of two major political parties' manifestos in Ghana. Through a corpus methodological approach, the study examines the lexical choices in the manifestos of the NDC and the NPP, allowing for investigations into the major thematic issues, the focus and strategies employed by the two political parties in writing their manifestos.

For the rest of the paper, I first discuss political campaigns and manifestos. Second, I provide a description of the research context and background to the NPP and NDC. The next section describes the methodology, including the theoretical lens, the corpus and methods of analysis. This is followed by results and discussion, and then conclusion.

\section{Political Campaigns and Manifestos}

Electoral campaigns are said to be the foundation of democratic governance (Druckman, Kifer, \& Parkin, 2009). The discourse of political campaigns revolves around several characteristic features, namely: sender - rival political actors made up of incumbents and challengers; message, which is agitational; channel, which is mostly indirect; receiver - voters; effect - obtainment or loss of electoral support; and time perspective - limited to election campaign (Dudek \& Partacz, 2009). From a functional standpoint, political campaign messages are manipulative, aimed at obtaining electoral support resulting in post appointing and real political power (Dudek \& Partacz, 2009). Political electoral campaigns are said to be deceptive, involve demagoguery, monetisation and apathetic voters (Benoit, 2017). One major feature of political campaigning is the production and use of manifestos. As Ayee (2011: 372) remarks, "to operate in the political market, one needs to present political products which include personalities, manifestos, ideology, past performance, and evidences of dependability and reliability". Manifestos document the strategic plans and policies of political parties, which inform voters about where parties stand on policy issues (Fernandez-Vazquez, 2018) and can be used as the basis of measuring the success, or otherwise, of democratic governments. Studying political party manifestos is, therefore, crucial for understanding several governance and policy issues, including rhetoric and practice/performance.

Political manifestos have been studied from different perspectives including: communication (Druckman et al., 2009); functional analysis (Benoit, 1999, 2017); content analysis (Netswera, 2016); critical discourse analysis (Ehineni, 2014; Moloi \& Bojabotseha, 2014; Kyerewaa-Owusu, 2017); and modality (Nartey \& Yankson, 2014). Ayee (2011: 380) provides a tall list of studies on factors affecting electoral victories, including manifestos, in the Americas and the West. The list indicates the proliferation of political campaign and manifesto studies in these areas. The studies show that the electorate in these areas make rational choices in their voting based on policies, ideology and philosophies of political parties. However, voting patterns in African elections have largely been influenced by ethnicity and "political tribalism" (Ayee, 2011: 367, 380).

Studies on political campaigns and manifestos around the world abound in the literature. For example, the Comparative Manifesto Project (CMP) provides a database of over 3,000 manifestos, which are coded into a scheme of 56 categories reflecting broad policy issues across Eastern Europe, the European Union and the Organisation for Economic Co-operation and Development (OECD) countries (Flentje, 2017). However, few of such studies are found in Africa in general and Ghana in particular, perhaps, because of the young nature of multiparty democracy in Africa.

In Africa, two studies on manifestos in South Africa and Nigeria are readily available, as per my search, especially from language and/or applied linguistic perspectives. Through a critical discourse analysis (CDA) approach, Ehineni (2014) explores the ideological underpinnings of modal auxiliaries in two gubernatorial manifestos in the Ondo State in the 2012 Nigerian gubernatorial elections. Ehineni (2014: 109) states that 
models are used "for persuasion, obligation, to make promises, demonstrate political will/commitment, and solicit public support and manipulation". He concludes that modals can be used as ideological tools. Moloi and Bojabotseha (2014) study the African National Congress' (ANC, South Africa) manifestos of 1999, 2004 and 2009 through CDA, focusing on intertextuality and interdiscursivity. They find that the ANC's manifestos are characterised by multiple texts and voices, which are reproduced and invoked to legitimise the ANC and its achievements, challenges and plans in its struggle to improve the socio-economic and political lives of South Africans. The manifestos also anticipate and engage critical and oppositional voices by identifying and acknowledging the challenges that confront the South African society. The study further indicates that the ANC manifestos "bracket or suppress meanings and norms that are different from the dominant ones" (p. 422). These findings imply that the ANC highlight their positives and supress the positives of their opponents and/or suppress their own negatives and highlight the negatives of their opponents, similar to Benoit's $(1999,2017)$ acclaim, attack and defence principles (see section on Theoretical lens). Ehineni's (2014) and Moloi and Bojabotseha's (2014) studies demonstrate the potential for linguistic studies of manifestos to help unearth the strategies and ideological underpinnings of manifestos in Africa.

Even though several studies can be found on elections in Ghana (see Ayee 2011: 381-382 for a list of examples), few of such studies have concentrated on manifestos. From a content analytical perspective, Ayee (2011) studies how manifestos influence electoral outcomes. Gyampo and Debrah (2013) employ Heywood's (2002: 242-244) theories of voting to analyse young people's views concerning Ghanaian electoral manifestos. The theoretical model includes party identification, sociological, rational choice and dominant ideology models. The study concludes that manifestos are important for promoting issue-based voting and reducing irrational voting tendencies among voters. From a language and/or linguistic perspective, Nartey and Yankson (2014) examine the semantics of modal auxiliary verbs in the 2012 manifesto of the New Patriotic Party (NPP). Nartey and Yankson (2014: 21) find that modal auxiliary verbs are used to indicate "a sense of intention, promise, obligation and necessity in a conscious and strategic attempt to persuade the electorate". They conclude that political rhetoric is conditioned by aims and exact themes. Kyerewaa-Owusu (2017) also does a critical discourse analysis of the 2016 manifestos of the NDC and the NPP. She finds that the manifestos employ several rhetorical strategies, including blame-game, self-praising, comparison, parallelism and overload of emotive language.

Although these studies make important contributions to scholarly research on manifestos in Ghana, albeit, selected manifestos, they do not give a comprehensive account of all the manifestos of the two political parties, compared to this study. Nartey and Yankson look at only the 2012 NPP manifesto without any comparison. Concentrating only on modal auxiliaries does not give a detailed account of the different facets of Ghanaian political parties' manifestos. While Kyerewaa-Owusu (2017) does a comparative analysis of the NPP and the NDC manifestos, she focuses only on the 2016 manifestos. The study does not provide a sense of the incremental or decremental uses of the strategies used by the two political parties, denying the reader an understanding of the contextual relevance of those strategies, as this paper does. Better still, and as far as I know, hardly has any study employed corpus methods to study Ghanaian political parties' manifestos. These make this study significant.

\section{Research Context and Background of the NPP and the NDC}

Ghana has had four different Republics, with four governance systems, namely: quasi-presidential system (1960), parliamentary (1969), presidential (1979) and hybrid of presidential and parliamentary (1992) (Ayee, 2011). The first three saw military interventions and takeovers, making the Fourth Republic the most enduring of all. In the 1992 elections that ushered in the Fourth Republic, five political parties contested. These were the National Democratic Congress (NDC), the New Patriotic Party (NPP), the People's National Convention (PNC), the National Independence Party (NIP) and the People's Heritage Party (PHP). As of 2008, 11 political parties had registered (Ayee, 2011) and by 2016, there were about 23 registered political parties in Ghana, even though only six contested the 2016 general elections, viz: the New Patriotic Party (NPP), the National Democratic Congress (NDC), the Convention People's Party (CPP), the Progressive People's Party (PPP), the National Democratic Party (NDP) and the People's National Convention (PNC). The NPP won the 2016 general elections. This study concentrates on the manifestos of the NDC and the NPP since they have alternated power throughout the Fourth Republic, that is: NDC, 1993-2000; NPP, 2001-2008; NDC, 2009-2016; and NPP, 2017-present.

Led by J.J. Rawlings, the NDC won both the December 1992 and 1996 elections; while the NPP's J. A. Kufuor won the 2000 and 2004 elections, ruling for eight years each. With J. E. A. Mills as the standard bearer, the NDC won the 2008 elections (Mills died in office in July 2012) and the then Vice President John Mahama took over as President immediately after the death of Mills. John Mahama subsequently won the 2012 elections but lost to the NPP' s Akufo-Addo in the 2016 general elections. 
The NPP is a liberal party, with a strong attachment to the ideals of liberalism, considering free enterprise as the foundation of socio-economic prosperity (Ninsin, 2006). Sharing traditions with rightist traditions such as the Republican Party of the United States of America and the British Conservative Party, the NPP sees the private sector as the engine of growth. It orients itself towards neo-liberal economic policies, where property owning is a key feature. The NDC, on the other hand, "is a Social Democratic Party that believes in the equality and the egalitarian treatment of all persons irrespective of their social, cultural, educational, political, religious and economic relations in a multi-party environment" (Article 5, NDC Constitution 1992). The NDC associates itself with the democratic left parties in the world, including the British Labour Party and the Democratic Party in the USA (Ninsin, 2006). The NDC has roots in the Provisional National Defence Council (PNDC) military regime that was led by J.J. Rawlings and ruled Ghana from 1981 to 1992. Rawlings formed the NDC in 1992 and subsequently led it to win power in both the 1992 and 1996 elections. Thus, cumulatively, the NDC has governed Ghana for 16 years, while the NPP, as of today, has governed for 10 years.

Ninsin (2006) has noted that, while the two political parties claim different ideological positions, they are not necessarily different in terms of practical formulation and implementation of policies. In other words, they are guided by a single dynamic logic of "the burning desires to exercise the democratic rights ... namely, the right to free choice, to self-determination, to association, and the right to associate freely" (Ninsin, 2006: 3). This implies that the manifestos of the two parties may be more similar than different. For instance, Gyampo and Debrah (2013) have indicated that the 2012 manifestos of the two parties were only different in name rather than substance, as they both pledged to make education a right, achieve quality health for all, create jobs and youth empowerment, reduce poverty, achieve gender equity and render good governance, among others. Whereas the manifestos may not be different in content, their ways of communicating ideas and the strategies employed could be materially different. This is because Ghanaian political campaigns are characterised by acrimony with name-calling, attacks and counter-attacks, even though Gyampo and Debrah (2013) think that the 2012 electoral manifestos were issue-based. This study is, therefore, significant as it explores the major thematic issues, the focus and strategies used by the two political parties in their campaign manifestos of 1996, 2000, 2004, 2008, 2012 and 2016.

\section{Methods}

This section discusses the theoretical lens and describes the data and methods of analysis.

\section{Theoretical Lens}

The study is based on the functional theory of political campaign discourse, which states that "candidates have three potential functions (acclaim, attack and defense [defence]) and two general topics (policy and character)" (Benoit, 1999: 208). In other words, the theory "argues that election messages address one of three functions (acclaims, attacks, defenses [defences]) and one of two topics (policy, character)" (Benoit, 2017: 7). The theory is based on six assumptions, namely: ( $i$ ) voting is a comparative act; (ii) candidates must distinguish themselves from opponents; (iii) political campaign messages are important vehicles for distinguishing between candidates; (iv) candidates establish preferability through acclaiming, attacking, and defending; ( $v$ ) campaign discourse occurs on two topics: policy and character; and ( $\mathrm{vi}$ ) a candidate must win a majority (or a plurality) of the votes cast in an election (Benoit, 2006: 11-17; 2007:32-61; Benoit \& Sheafer, 2006). The theory further maintains that the broad functions of acclaim, attack and defence can be broken down "into useful categories (policy: past deeds, future plans, general goals; character: personal qualities, leadership ability, ideals)" (Benoit, 1999: 203). The theory provides a useful method for analysing and understanding political campaign messages, as it "articulates assumptions about election discourse and offers several predictions about the content of campaign messages" (Benoit, 2017: 10). The hypothesis is that challengers attack the record, accomplishments and policies of incumbent governments while calling for change and expressing the hope and optimism for the future, whereas incumbents defend their records and policies (Benoit, 2007; Druckman et al., 2009; Trent \& Friedenberg, 2008).

Developed in the United States by Benoit (1999), the functional theory has been applied variously. According to Benoit (2017), it has been applied in several election campaign messages, including: candidacy announcement speeches; TV spots; political campaign; (vice) presidential debates; candidate webpages; nomination acceptance addresses; senate, gubernatorial, mayoral debates, etc. in the US and other countries. This indicates the versatility of the theory. As noted by Benoit (2017: 12), the usefulness of the theory has already been acknowledged by many scholars, viz:

This approach has received growing acceptance. For example, Nai and Walter (2015: 17) edited a book on negative campaigning, adopting Functional Theory 'as a baseline for defining and measuring negative campaigning'. Hrbkova and Zagrapan (2014), studying political leaders' 
debates, wrote that "The most influential attempt at systematic analysis of political debates based on a specific theoretical construct is the functional theory by William Benoit" (p.736). Isotalus (2011) wrote that "One of the most used and systematically tested theories in the studies of the content of television debates has been functional theory" ( $p$. 31). This theory merits scholarly attention.

Although most of the research employing the functional theory has been in North America, including the United States and Canada (Benoit, 1999, 2006, 2007, 2011; Benoit \& Henson, 2007), a growing number can be found in other continents and countries around the globe. It has been applied to political (campaign) discourse in Europe, including the United Kingdom (Benoit \& Benoit-Bryan, 2014), France (Choi \& Benoit, 2016), Finland (Isotalus \& Aarnio, 2005), and Poland (Dudek \& Partacz, 2009). In Asia, the theory has similarly been applied in countries such as South Korea (Choi \& Benoit, 2016), Kuwait (Alqaseer, 2013) and Australia (Benoit \& BenoitBryan, 2015). It has equally been employed in political campaign studies in Africa, in countries such as Nigeria (Ademilokun, 2015), Kenya (Kiage, 2015), and two of such studies can be found in Ghana (Amegatcher, 2015; Fordjour, 2015). These studies demonstrate the adaptability of the theory to different political contexts and cultures. Notwithstanding this versatility, it has been argued that the theory is not suitable for all political campaigns and all cultures, as, for example, multiparty democracies, in which political campaign discourse is wide-ranging (Isotalus, 2009, 2011; Isotalus \& Aarnio, 2005, 2006). The theory also appears to be suitable only for two-party systems, where there usually seems to be a clear predictable winner, such that the character of the candidates can be an issue for debate (Isotalus, 2011). The assumption in Isotalus $(2009,2011)$ and Isotalus and Aarnio $(2005,2006)$ is that the issue of character attacks may not be applicable in multiparty democracies because when the candidates are many, it is difficult to target one candidate's character. However, one may argue that even if the candidates are many, they can still attack each other' $s$ character in several ways, even though the attacks may not be as forceful as in two-party systems. The cultural perspective may be the most important because, in cultures where character and personality attacks are frowned upon, the aspect of the theory which deals with attacks may not be applicable. For example, Isotalus and Aarnio $(2005,2006)$ indicate that attacks and defences are not fundamental in Finnish political campaign communication.

The above-stated arguments call for more empirical studies in different socio-political contexts in order to further test the theory and its applicability. Also, the majority of studies employing the functional theory seemed to be more interested in spoken discourse than written discourse. Few of them have concentrated on written campaign discourse, such as manifestos of political parties. This makes the current study significant as it helps to expand the frontiers of the application of the functional theory.

\section{The Corpora}

Two sub-corpora are used for this study: the manifestos of the New Patriotic Party (NPP) and the National Democratic Congress (NDC) for elections 1996, 2000, 2004, 2008, 2012 and 2016, excluding the NPP' s 2004 manifesto, which was unavailable. They were all in their soft copy forms, which made it possible for the application of the corpus methodological analysis. The manifestos were cleaned to remove pictures and any other irrelevant items that could mar the application of the Wordsmith Tools and the analysis. The NPP manifesto corpus amounted to 125,710 running words, with 8,196 distinctive words, while the NDC manifesto corpus was 129,326 running words, with 8,647 distinctive words.

\section{Method of Analysis}

This study is a corpus-based study, that is, a "computer-aided analysis of very extensive collections of transcribed utterances or written texts" (McEnery \& Hardie, 2012: i). It employs the use of Wordsmith Tools version 6 (Scott, 2012), which is a lexical analysis software programme that allows a language/linguistic analyst to observe words/linguistic items in their linguistic contexts so as to be able to interpret them co-textually. The analysis involved a three-step approach.

1. First, I ran a wordlist of each of the two corpora to generate the total number of words in each of them and their frequencies. The wordlist tool lists all the words in the corpus and arranges them by frequency and alphabetically (Scott, 2001).

2. Second, I ran and generated keyword lists by comparing the NPP wordlist with the NDC wordlist and vice versa. A keyword list identifies the unusually frequent words in a dataset (Gabrielatos \& Baker, 2008: 10; Scott, 1997) when compared with a reference corpus. It allows for comparing "the frequencies in one wordlist against another in order to determine which words occur statistically more often in wordlist A when compared with wordlist B and vice versa" (Baker, 2006: 2). In other words, keyword list is useful for identifying lexical differences between texts (Baker, 2006) and the "aboutness" of each dataset, that is, what the data is about (Bondi, 2010: 7-8). 
3. I used concordance to index the keywords in order to examine the semantic/discourse prosodies of the various keywords so as to determine the themes and concepts associated with the keywords. A concordance is a tool that locates all references to a given word or phrase within a corpus and shows "them in standard concordance lines with the search word centred and a variable amount of text at either side", allowing for the examination of the collocates of the word (Scot, 2001: 47), thereby determining the semantic prosody, "a form of meaning which is established through the proximity of a consistent series of collocates” (Louw, 2000: 57).

The keywords and the concordances helped to identify the strategies and focus of the NPP and the NDC manifestos, that is, whether they were issue-centred or personality-centred.

\section{Results and Discussion}

This section examines the keywords in the corpora and their semantic/discourse prosodies so as to explore the themes, concepts and strategies employed in the two sets of corpus.

\section{Keywords and Themes in the NDC and the NPP Manifestos}

To identify the themes and key concepts that characterised the two sets of manifestos, I generated keyword lists for the two sets of data. Figure 1 indicates the first 26 keywords, as generated through Wordsmith Too/s, for each of the two datasets. They are words that appeared within the first five percent $(5 \%)$ of the keywords in the two corpora.

For each of the NDC and NPP keyword lists, the first $(\mathrm{N})$ column reprsents the order in which the words were presented, in a descending order. The second column is the list of the words, while the third column indicates the frequency of each word. The percentage (\%) column shows the figure as a percentage of the subcorpus. The Texts column shows the number of manifestos in which each word appears. The reference corpus (RC) columns show the raw (column 6) and percentage (column 7, RC \%) frequencies of the keywords in the other corpus. The keyness column assigns a keyness value to each keyword, where the higher the score the stronger the keyness of that word. The final column denotes the $p$-value of each word, where $p$ is set so low (0.00000), indicating the strength of the keyness values and giving a more gradable strength of each word (cf. Baker, 2006).

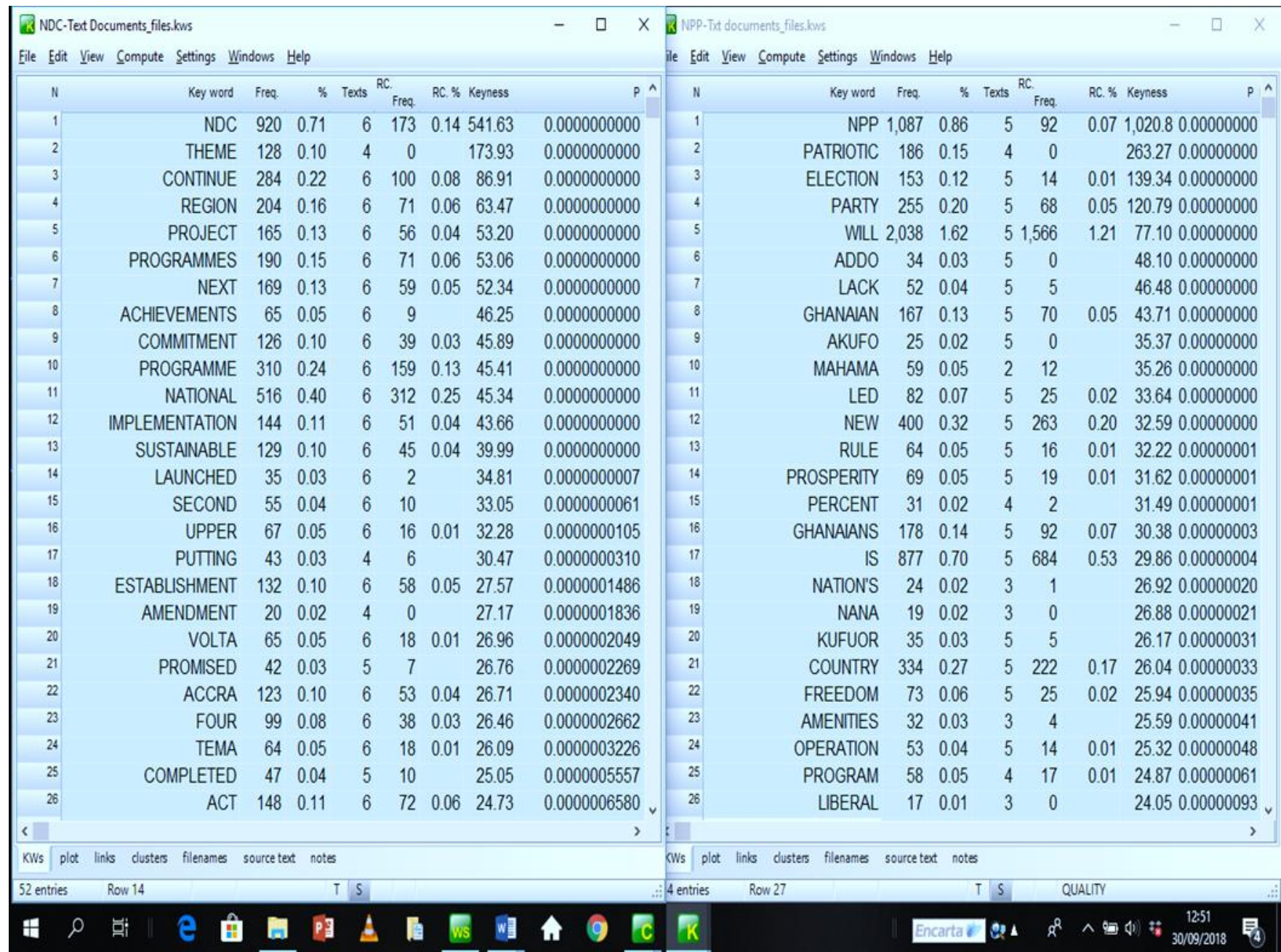

Figure 1: Keywords and their frequencies and keyness in the NDC and NPP manifestos 
Figure 1 indicates that the NDC manifestos mostly focus on policy issues (theme, achievements, commencement, launch or completion of projects/programme[s]) and geopgraphical locations (region, upper [East and West], volta, Accra and Tema). The NPP, on the other hand, focus on their ideology (freedom, rule, liberal, and prosperity) and personality/character, as three key names appear in the NPP manifestos. These names are Mahama (the NDC vice presidential candidate in the 2008 general elections, vice-president from January 7, 2009 to July 2012; president/presidential candidate in the 2012 and the 2016 general elections); Akufo-Addo, the NPP presidential candidate in the 2008, 2012 and 2016 elections); and Kufuor, the president of Ghana under the NPP government of 2001-2008. The presence of the names is discussed in antepenultimate and penultimate section.

\section{On Policy, Strongholds and Ideology}

The NDC, through policy-indicator and geographically-pointer keywords, procalim their policy orientation and demonstrate attachment to their strongholds in order to show the concentration of a set of their policies. The majority of the keywords are used in relation to policy planning and execution. For example, the 2016 NDC manifesto states: "our policies, programmes and projects have been directed at putting people first, building a strong and resilient economy, expanding infrastructure for accelerated growth and jobs, and advancing transparent and accountable governance". They indicate their past and present deeds, and future plans (Benoit, 1999), such as having "completed" (lines 17-20, Figure 2) the construction of modern cold

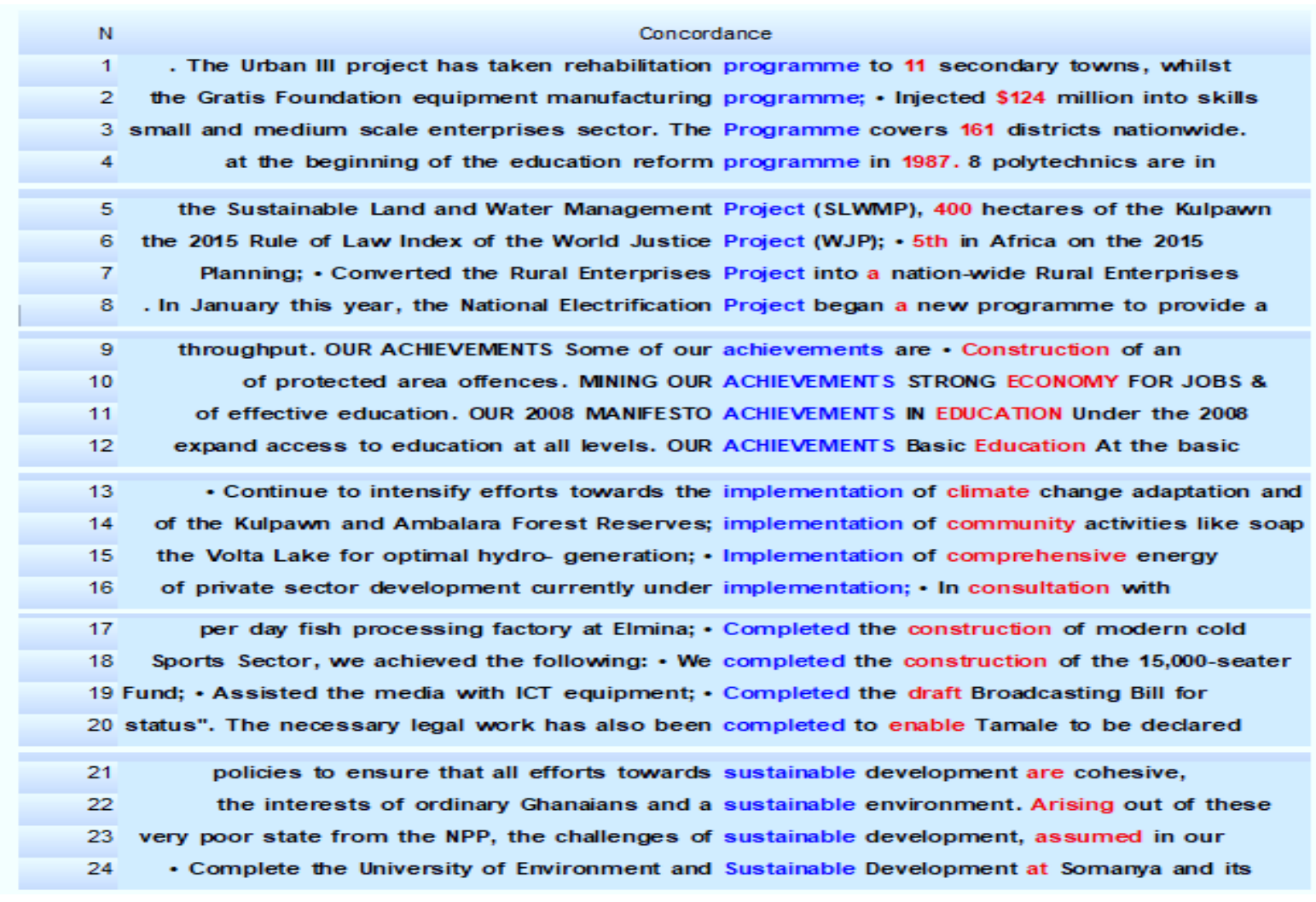

Figure 2: Sample concordance lines indicating policy-oriented keywords in NDC manifestos

stores and 15,000-seater capacity Cape Coast Stadium; having taken the rehabilitation "programme" (lines 14) to 11 secondary towns (line 1); supported 500 young people through the Gratis Foundation equipment manufacturing "programme" (line 2). They also talk about achievements in the economy and education (lines 9-12), and projects that have been completed (lines 5-8), while working to implement other policy programmes (lines 13-16) and projecting into a future of sustainable development (lines 21-24). Recounting the past and present deeds indirectly debunks oppositional voices and criticism, and justifies the request for another opportunity to govern the country, similar to what Moloi and Bojabotseha (2014) find in ANC manifestos. 
The NDC manifestos also expound attachment to the NDC's strongholds by making references to such places (see Figure 3). The Upper East and Upper West (lines 5-8) and Volta (lines 9-12) regions are known NDC strongholds, while the Greater Accra Region (lines 13-16), including Tema (lines 17-20), is an important political enclave for both political parties as a result of its swing nature and determination of elecotral outcomes. The assumption is that the NDC (have) either initiated, commenced or completed programmes and projects in these areas.

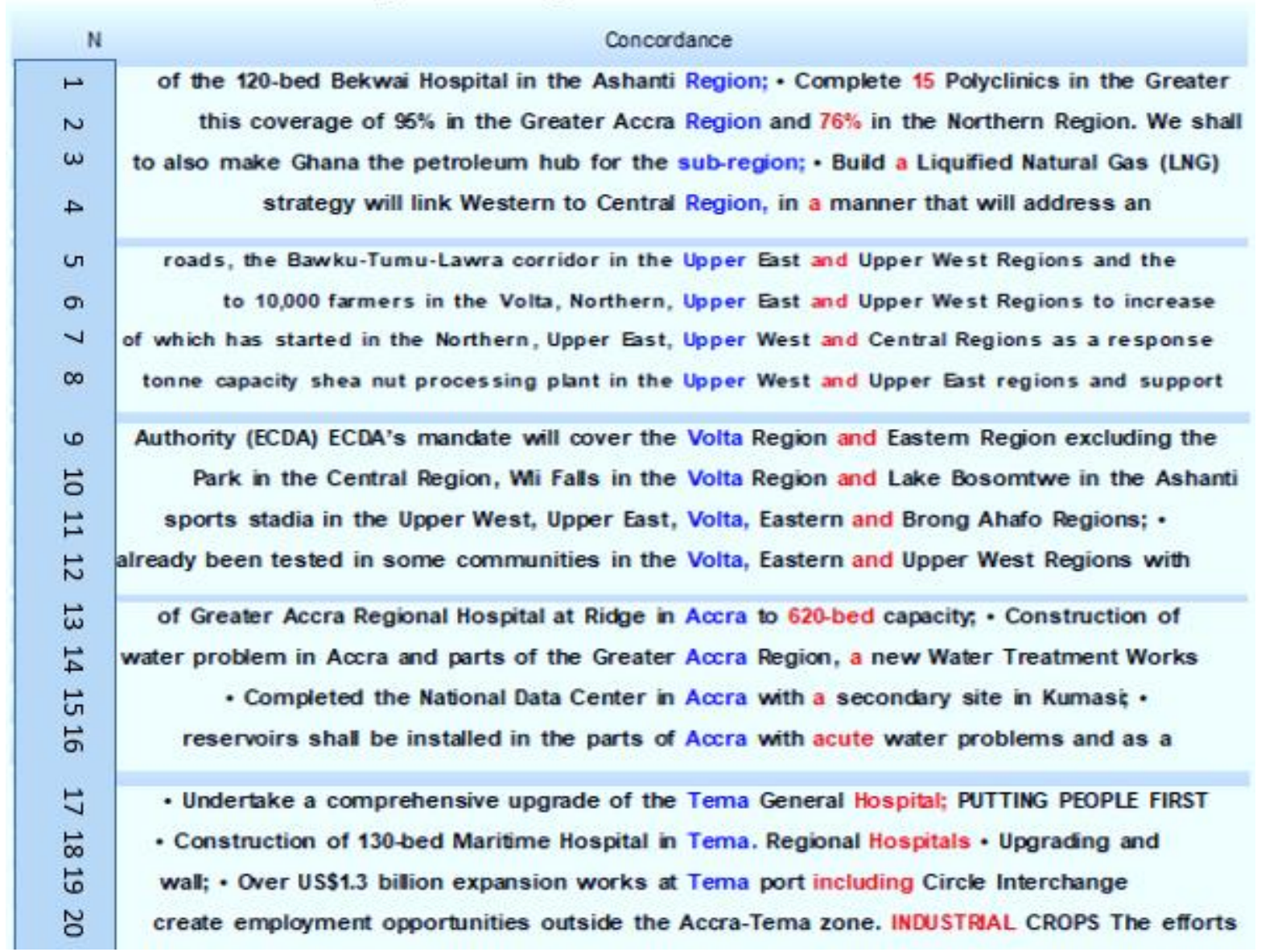

Figure 3: Sample concordance lines indication geographical locations mentioned by the NDC

Linking policies and projects undertaken to geographical and territorial areas is important because, as noted by Chilton (2004: 57), spatial referencing in political discourse is of great importance, for "[i]f politics is about cooperation and conflict over allocation of resources, such resources are frequently of a spatial, that is, geographical or territorial, kind". It reflects the statement that, in parliamentary discourse, references to territorial areas is a means of indicating concerns for the people, and demonstrating how government policies affect such areas (Sarfo-Kantankah, 2019). 
The keywords that characterise the NPP manifestos point to two main themes: their ideological position and candidates' character (character is discussed under the antepenultimate section). The NPP' $s$ political ideology includes the freedom of association (see Figure 4, lines 1-4), the rule of law (lines 5-8), liberal democracy (lines 9-13) and bringing prosperity to people (lines 14-17).

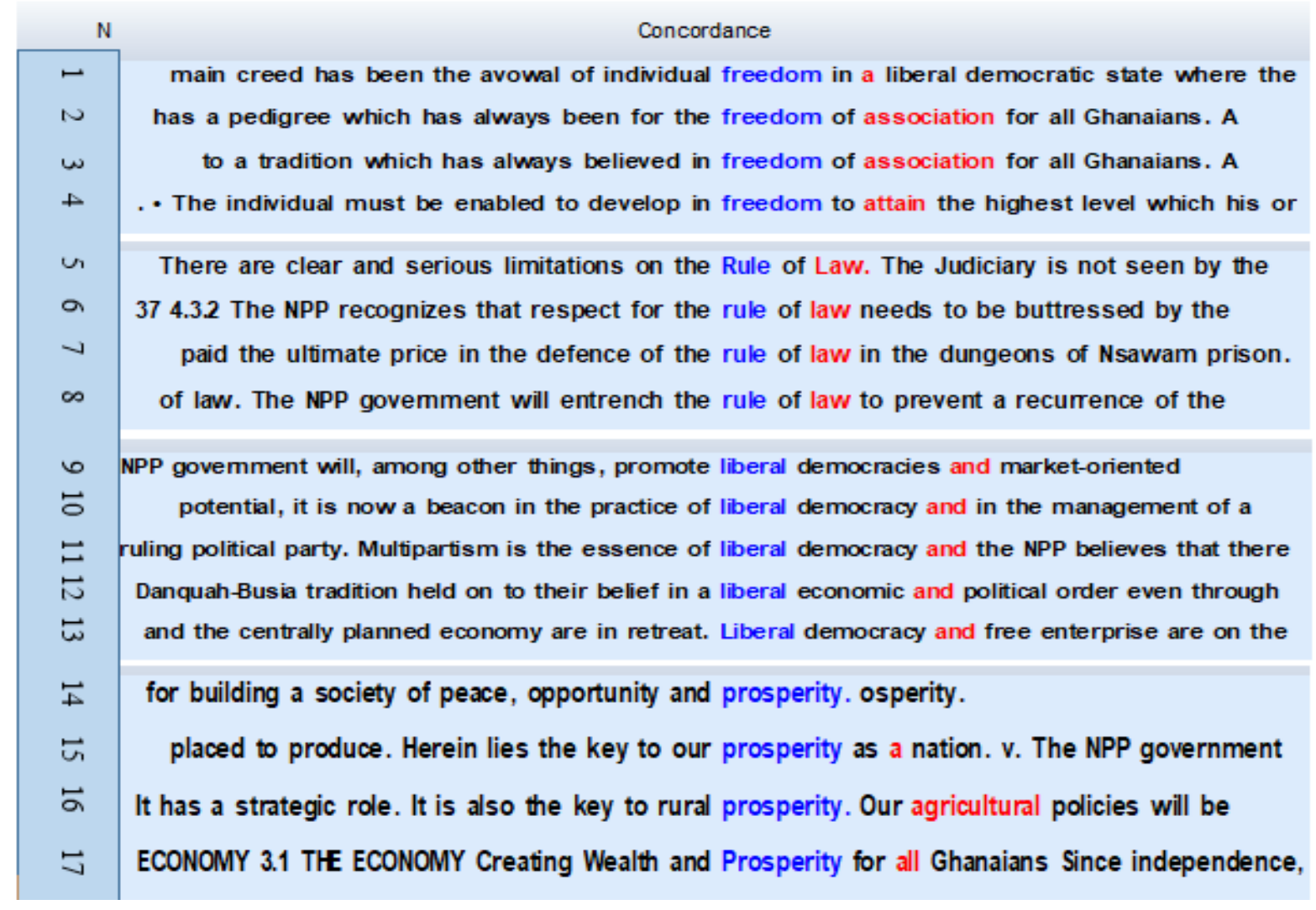

Figure 4: Sample concordance lines of keywords indicating NPP's ideological position

The NPP consider themselves as promoters of liberal democratic principles, being advocates of "freedom" (lines 1-4) of association and attainment of economic development and prosperity for all Ghanaians (lines 14-17). Being liberal democrats, they respect the rule of law (lines 5-8) and free enterprise (line 13). While these demonstrate the NPP's “general goals", they also indicate their "future plans" (Benoit, 1999: 203), including the entrenchment of the rule of law to prevent recurrence [of human rights violations of the past], and envisaging a Ghana "whose governance is imbued with the principles of liberal democracy, the rule of law, respect for human rights and social justice" (NPP 1996 manifesto). The foregoing supports the assumption that political manifestos express political parties' ideologies and their political ideas (cf. Ehineni, 2014). 


\section{Keywords and Themes Across Years}

This section examines the keywords and their occurrences across the years in order to gauge the extent to which these keywords and themes mattered to the political parties vis-à-vis the political contexts and issues that surrounded each political campaign period. This will help understand the impact of the themes on various elections that were held.

Table 1 shows that the use of the keywords (see italics) in the NDC's manifestos was incremental over the years. Generally, the highest numbers occurred in 2012 and 2016 . This implies that the NDC's campaigns became more issue-based as the years went by. It shows the NDC' s orientation towards a policybased campaign aimed at fashioning out programmes to meet the people's aspirations. It also implies the NDC's recognition of the people's concern, that is, "the sense of putting people' s interests at the forefront of policy - the idea that public policies should cater for the socio-economic wellbeing of the people" (SarfoKantankah, 2018: 398).

Table 1: Keywords Frequency in NDC Manifestos Across Years

\begin{tabular}{|l|l|l|l|l|l|l|l|}
\hline Keyword & \multicolumn{9}{|c|}{ Year } & Total \\
\hline & 1996 & 2000 & 2004 & 2008 & 2012 & 2016 & \\
\hline Theme & 00 & 01 & 00 & 07 & 49 & 71 & 128 \\
\hline Project & 22 & 32 & 32 & 18 & 49 & 94 & 247 \\
\hline Programmes & 18 & 25 & 30 & 17 & 67 & 33 & 190 \\
\hline Achievements & 03 & 02 & 02 & 03 & 13 & 42 & 65 \\
\hline Implementation & 02 & 12 & 13 & 12 & 54 & 51 & 144 \\
\hline Completed & 10 & 07 & 01 & 00 & 05 & 24 & 47 \\
\hline Sustainable & 06 & 09 & 14 & 32 & 28 & 40 & 129 \\
\hline Commitment & 16 & 14 & 16 & 16 & 11 & 53 & 126 \\
\hline Launched & 01 & 07 & 04 & 02 & 07 & 14 & 35 \\
\hline Putting & 01 & 00 & 01 & 00 & 16 & 25 & 43 \\
\hline Establishment & 09 & 09 & 19 & 13 & 50 & 32 & 132 \\
\hline Promised & 03 & 09 & 05 & 00 & 23 & 02 & 42 \\
\hline National & 42 & 69 & 105 & 55 & 124 & 121 & 516 \\
\hline Region & 05 & 17 & 14 & 13 & 96 & 119 & 204 \\
\hline Upper East/West & 02 & 03 & 03 & 04 & 13 & 42 & 67 \\
\hline Volta & 01 & 04 & 05 & 07 & 11 & 37 & 65 \\
\hline Accra & 06 & 15 & 15 & 10 & 20 & 57 & 123 \\
\hline Tema & 08 & 06 & 07 & 07 & 12 & 24 & 64 \\
\hline Total & 155 & 241 & 286 & 216 & 648 & 881 & 2367 \\
\hline
\end{tabular}

In the NPP manifestos, the use of most of the keywords was either incremental or decremental over the years. For the NPP's ideological position such as the rule of law and liberal democracy, the frequency of the keywords (see italics) was decremental: it was more in the 1996 and 2000 manifestos. This is significant because those were the formative years of the NPP and, therefore, they needed to tell the people of Ghana what they stood for. As Hahn (1998: 14) notes, "ideologies cannot be developed, sustained, or challenged except through communication [or discourse]. And communication cannot occur without reflecting the ideology of the speaking individual and the society of which (s)he is a member". Again, it was the time when the NDC was led by J.J. Rawlings, who was the military leader of the country in 1979 and then 1981-1992; who was said to have curtailed the rule of law as a result of the military rule. Rawlings was accused of human rights abuses. 
Thus, the NPP wanted to let the people of Ghana know that they stood for the rule of law. However, those issues were less relevant in the 2008, 2012 and 2016 elections because the NPP had had the opportunity of governing the country for eight years and did not need to talk about their ideological orientations anymore, since the issues had become self-evident to Ghanaians.

Table 2: Keywords Frequency in NPP Manifestos across Years

\begin{tabular}{|l|l|l|l|l|l|l|l|}
\hline \multirow{2}{*}{ Keyword } & \multicolumn{9}{|c|}{ Year } & Total \\
\hline & 1996 & 2000 & 2004 & 2008 & 2012 & 2016 & \\
\hline Election & 01 & 02 & & 02 & 02 & 146 & 153 \\
\hline Lack & 07 & 09 & & 03 & 23 & 10 & 53 \\
\hline Ghanaian(s) & 56 & 79 & & 69 & 61 & 80 & 345 \\
\hline Nation's & 06 & 07 & & 11 & & & 24 \\
\hline Country & 47 & 45 & & 54 & 47 & 147 & 334 \\
\hline Freedom & 18 & 14 & & 09 & 07 & 25 & 73 \\
\hline Rule & 20 & 25 & & 06 & 09 & 04 & 64 \\
\hline Liberal & 08 & 07 & & 02 & & & 17 \\
\hline Prosperity & 15 & 20 & & 04 & 21 & 09 & 69 \\
\hline Amenities & 04 & & & & 27 & 01 & 32 \\
\hline Program & 29 & 19 & & & 05 & 05 & 58 \\
\hline Percent & 06 & 13 & & 11 & & 01 & 31 \\
\hline Quality & 30 & 20 & & 15 & 40 & 36 & 141 \\
\hline Akufo-Addo & 01 & 01 & & 04 & 19 & 09 & 34 \\
\hline Mahama & & & & & 03 & 59 & 62 \\
\hline Kufour & 01 & 01 & & 05 & 11 & 18 & 36 \\
\hline Total & 249 & 262 & & 195 & 275 & 550 & 1531 \\
\hline
\end{tabular}

On Personalities: Creating a Credible Self, Discrediting the Opponent

The NPP in their campaign manifestos create a credible and reputable candidate, while describing and smearing the opponent as discreditable through character account - personal qualities, leadership ability and ideals (Benoit, 1999). This is akin to Kyerewaa-Owusu's (2017) finding that there was self-praising and comparison in the 2016 manifestos of the NDC and NPP. Figure 5 is the first 26 of the 34 concordance lines of AkufoAddo, while Figure 6 is the first 26 of the 62 concordance lines of Mahama in the NPP manifestos.

The NPP' s concentration on personalities speaks to Mayer' s (1996: 445) argument that “[t]he issue positions assumed during a campaign $\cdots$ are short-lived and changeable; a better guide to what a candidate will do is often provided by his personality and character". There is a clear examination and judgement of Akufo-Addo's and Mahama's personality and character.

The Akufo-Addo concordance lines give a positive semantic prosody (cf. Louw, 2000), conveying the NPP's attitude towards Akufo-Addo. Akufo-Addo, who "has declared his intention" (line 1) is positively described as "competent, committed, experienced" (line 2) and "determined to identify the best people and develop new talents" (line 4). As a party, the NPP is portrayed as "committed" (lines 2, 6), having "prepared itself to deliver" (line 5) and holding "the transformation agenda" (line 3); it believes in democracy and the rule of law (line 8) and "will promote a shift towards crime prevention" (line 7). The leadership of Akufo-Addo is seen as one which will work for the good of the country (lines 9-11). On policy, the NPP under the leadership 
of Akufo-Addo will give priority to education (line 12), embark on public investment to provide basic amenities and support job creation (line 14), provide prosperity to the people (line 15), choose to invest in the future of the people (line 16), and build a strong economy (lines 19-20). The NPP raises hopes for a better future (lines 21-22), while admonishing the people to vote for Akufo-Addo and the NPP.

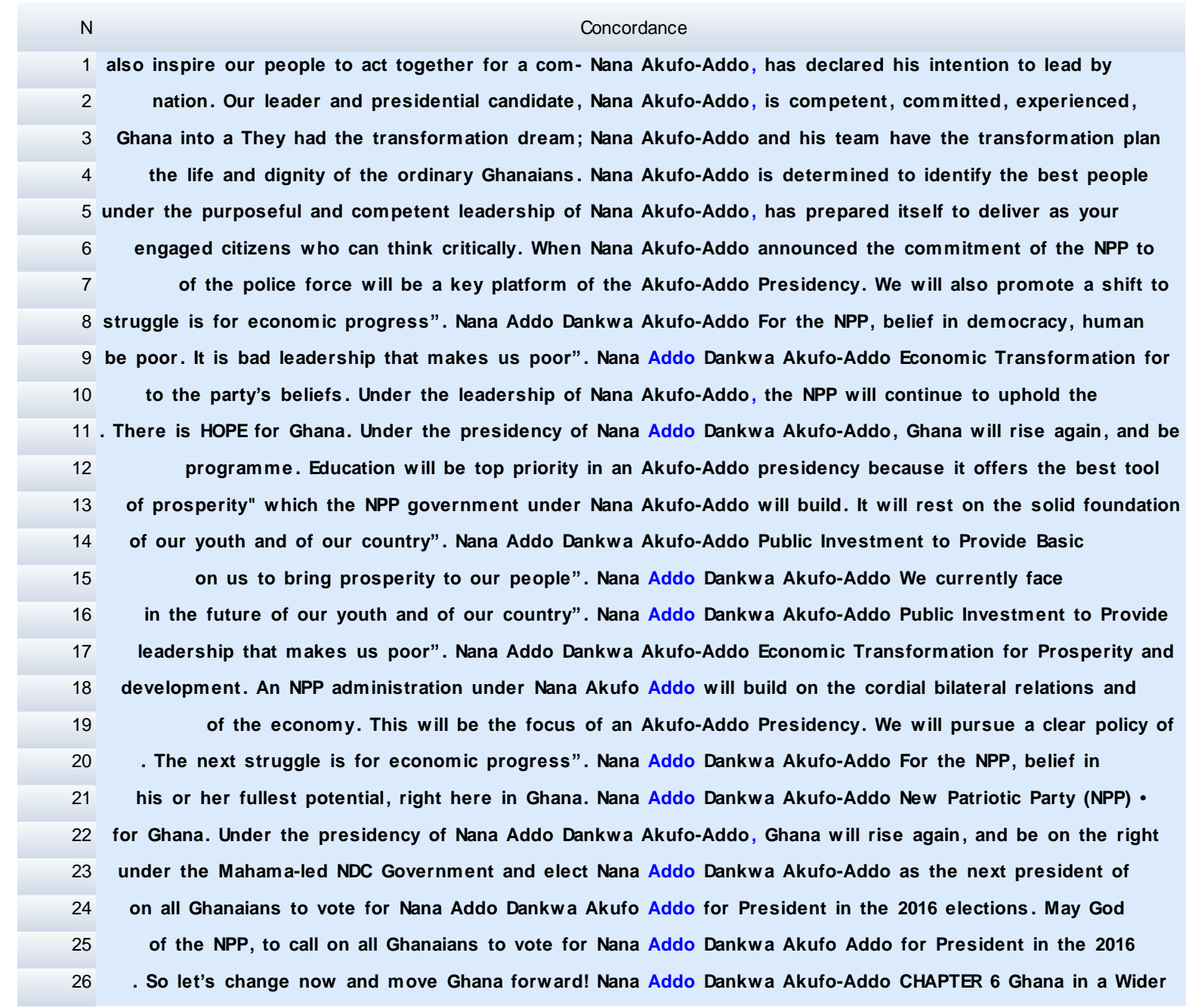

Figure 5: 26 of 34 concordance lines of Akufo-Addo

The NPP manifestos employ a negative campaign (Mayer, 1996), describing the weaknesses and faults of Mahama, the opponent, which Benoit (1999: 208; 2017: 7) terms as "attack". It is important to recognise that Mahama occurs almost twice (62) as Akufo-Addo (34) in the NPP manifestos. Mahama occurs three (3) times in the 2012 and 59 times in the 2016 manifestos. Akufo-Addo occurs once in 1996 and once in 2000, four (4) times in 2008, 19 in 2012 and nine (9) in 2016. This implies that there was more focus on Mahama than Akufo-Addo (the NPP's own candidate).

The concordance of Mahama gives a negative semantic prosody (cf. Louw, 2000), expressing the NPP' s negative attitude towards Mahama and evaluation of his deeds. Mahama is described as a failure (lines 2, 6), a bad steward (line 3), who has run out of things to blame Dumsor on (line 1); and his greatest legacy to Ghana as President is Dumsor (erratic power supply). Kyerewaa-Owusu (2017) refers to this type of strategy as apportionment of blame, where political parties blame incumbent governments and/or each other for the failures of the state. The NDC as a party and government is also depicted as having failed in various policy perspectives. 
It is described as "ineptitude" (line 8) and accused of "nepotism and cronyism", "mismanagement, incompetence and corruption" (line 9, 21). Corruption has become legendary (lines 10,11, 12, 13, 25); there is drug trafficking (line 16); increasing crime and lawlessness (line 18); reckless borrowing (line 19); and that the country is not working (line 23) under the Mahama-led NDC government. Note the expression "Mahama-led NDC government".

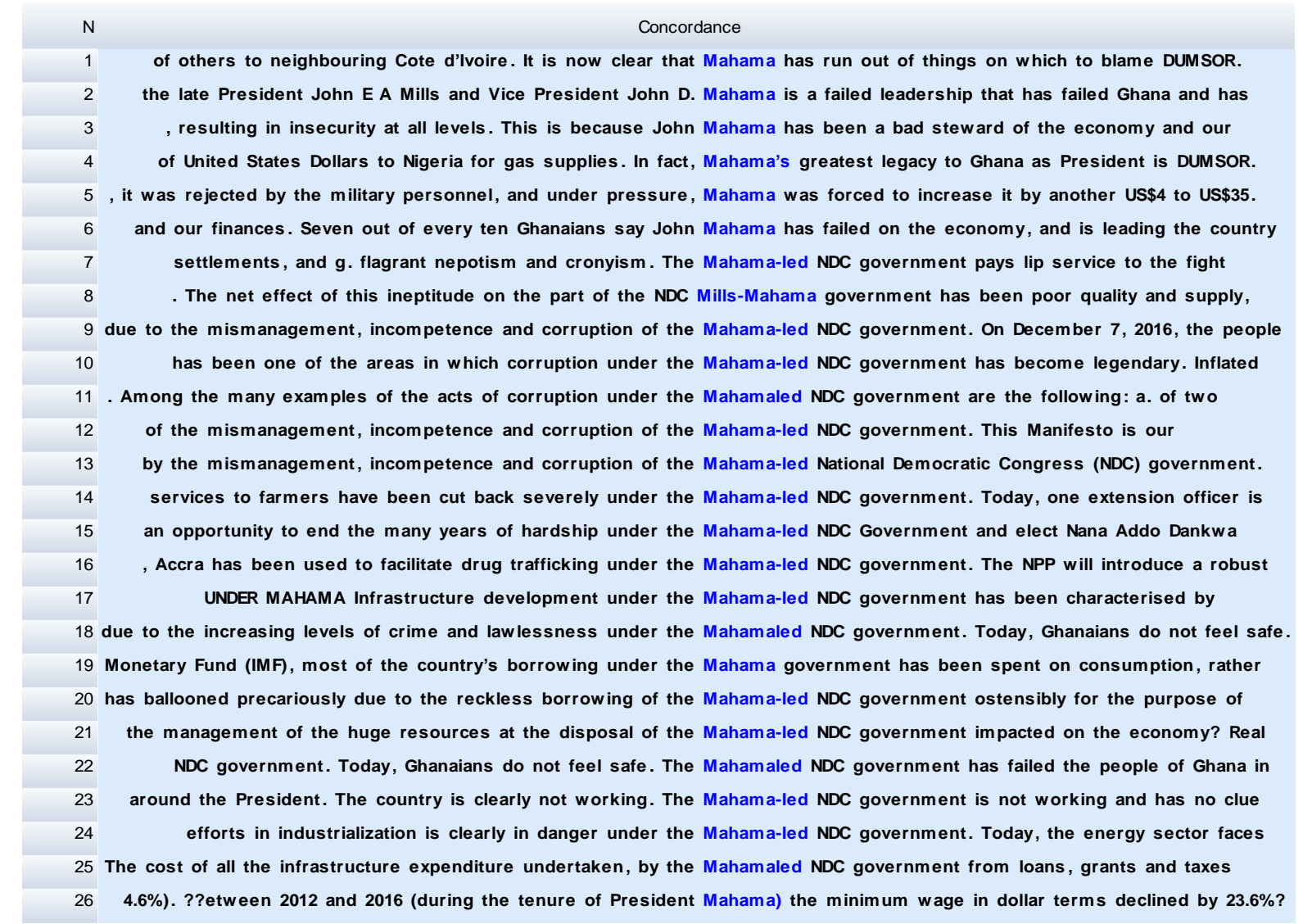

\section{Figure 6: 26 of 62 concordance lines of Mahama}

To attach Mahama to NDC and government instead of saying the "NDC government" or simply "the government" is instructive. It is a means of showing that Mahama is in control of everything and that if the government has failed it is Mahama who has failed. Thus, the focus on Mahama in the 2012 and 2016 manifestos of the NPP is significantly strong.

The NPP sought to sharply draw a contrast (cf. Kyerewaa-Owusu, 2017) between Akufo-Addo and Mahama through personality and character narratives. While the NPP portray Akufo-Addo as a trustworthy person, they describe Mahama as corrupt. This affirms Benoit's (1999, 2006, 2007, 2017) and Benoit and Sheafer's (2006) acclaim and attack principles as well as Nartey and Yankson's (2014: 29) finding that the NPP 2012 manifesto "positively project[ed] the NPP before the electorate, while at the same time highlight[ed] the supposed inefficiencies and incompetence of the incumbent government and governing party". The positivenegative descriptive dichotomy emanates from the fact that Akufo-Addo as a presidential candidate had been described by opponents as being arrogant, temperamental and violent such that his leadership as a president could be detrimental to the peace of the country. Thus, he had to fight off a lot of character issues. It is not surprising, therefore, that he was described by the NPP as competent, credible and incorruptible. To make such a description convincing, there was the need to juxtapose his personality and character against Mahama's, so as to make the electorate compare and see Akufo-Addo's strengths through the weaknesses of Mahama. It is instructive to know that the references to Mahama and his character could be found only in the 2012 manifesto, where it occurred only three (3) times, and 2016 where it occurred 59 times. Such a comparison affirms the findings of Kyerewaa-Owusu (2017) that there were uses of contrast and blame-game as rhetorical strategies in the 2016 manifestos of the NDC and the NPP. This points to what I call contextual relevance of the message or strategy. In 2008, Mahama was just the vice-presidential candidate and therefore a focus on him could not amount to any substantial political point scoring. However, as the presidential candidate, Mahama was a very significant figure in the scheme of things and everything was about him. In this sense, discrediting him was crucial for the projection of Akufo-Addo as a presidential candidate of the NPP.

Such character distinctions are significant, because, as Mayer (1996: 442) notes, negative portrayals of political opponents are

valuable on their own terms, for they tell us something extremely relevant about the choices we are about to make. We need to find out about the candidates' strengths '. , but we also need to learn about their weaknesses; their abilities and virtues they don' t have; the mistakes 
they have made; the problems they haven' $t$ dealt with; the issues they would prefer not to talk about; the bad or unrealistic policies they have proposed. If one candidate performed poorly in his last major public office, if another has no clear or viable plan for dealing with the economy, if a third is dishonest, the voters really do need to be informed about such matters.

Mayer (1996: 446) further argues that character attacks and negative campaigns are not necessarily bad, for "[i]f candidates are free to portray themselves as leaders or deep thinkers or good managers or highly moral, then their opponents should be free to contest these claims". This is important because a challenger to an incumbent has an obligation to demonstrate the weaknesses and shortcomings of his opponent and indicate how different and better he/she is. The foregoing points to van Dijk's (1997: 30) position that good policies of opponents may "be discredited by ad hominem attacks on opponents, and vice versa, [while] bad policies may be concealed by focussing attention on the good qualities or intentions of those who defend them" (van Dijk, 1997: 30). While Mayer' s (1996) and van Dijk's (1997) arguments are cogent, it should be recognised that, even though Ghana has experienced negative campaigning over the years, dating back to pre-independence (Bentil \& Aidoo, 2018), Ghanaian cultural norms frown upon negative campaign/politics such as personality attacks and politics of insults. There has been a major public concern over the upsurge of insults and acrimony in Ghanaian political discourse (cf. Ankrah, 2016; Asamoah et al., 2014; Ofori, 2017).

\section{Riding on the Back of the Good Work of a Previous Government}

In the 2008, 2012 and 2016 manifestos, the NPP sought to run on the back of the achievements of the Kufuorled NPP government of 2001-2008. It is quite interesting that Kufuor occurs more (36 times) than Akufo-Addo (34 times) in the manifestos of the NPP. Kufuor occurs once in the 1996 manifesto and once in the 2000 manifesto, even though he was the presidential candidate. But Kufuor occurs five (5) times, 11 times and 18 times in the 2008, 2012 and 2016 manifestos respectively.

The use of Kufuor's name in the manifestos of 2008, 2012 and 2016 points to "acclaim" (Benoit, 1999: 208; 2017: 7) or self-praise (Kyerewaa-Owusu, 2017), an attempt to use the Kufuor administration's performance as a springboard (lines 1-12): "We will continue the programme of the Kufuor government" (line 1); "It will rest on the solid foundation laid by the Kufuor administration" (line 2); "We will revive the implementation of the original Kufuor policy of free maternal healthcare" (line 3); "We will build on the achievement of the Kufuor government" (line 9). Kufuor is said to have initiated a number of programmes and policies (line 18) that will give an Akufo-Addo government good grounds for a take-off (lines 13-18). These include: "a new realignment of [salaries and a pension scheme for the armed forces]" (line 13); a Sports Bill (line 14); the "Municipal Finance Bill" (line 15), which will be passed into law under Akufo-Addo; and "National Transport Policy" (line 16). Again, the achievements of the Kufuor administration are stated (lines 19-26), including: moving Ghana "from a highly indebted poor [country to a middle income country as at 2008]" (line 21); bringing "back dignity to the Presidency" (line 22); improving the health of Ghanaians (line 24) and the "economy" [by attaining a GDP growth rate of 9.1\%] (line 25) and raising pension benefits (line 26). The abovementioned statements are a means of demonstrating the competence and effectiveness of the NPP as a team of which candidate Akufo-Addo was part, thereby underscoring how effective an Akufo-Addo government would be.

Two reasons are also adducible for the references to Kufuor and his administration, namely: (i) to reconcile the Kufuor-Akufo-Addo relationship, and (ii) to refute suggestions in the media that Kufuor and AkufoAddo had a strained relationship starting from the perception that Kufuor did not support Akufo-Addo in the 2008 elections (Mordy, 2014; Osam, 2014). In 2014, Akufo-Addo issued a press statement to debunk the allegations of a fractured relationship between him and Kufuor:

My attention has been drawn to ongoing media reportage and commentary being made by some members of the New Patriotic Party, and, unsurprisingly, by our political opponents to the effect there is a fractured relationship between President John Agyekum Kufuor and myself. The allegations that are making the rounds include the fact that President Kufuor did not support my presidential bids in 2008 and in 2012, and is also not in support of my bid to lead the party into the 2016 general elections, amongst others. I would like to place on record that these allegations, pointing to an unhealthy relationship between President Kufuor and myself, are false (Osam, 2014, n.p.) 
1 potable water. We will continue the programme of the Kufuor government, which undertook major water build. It will rest on the solid foundation laid by the Kufuor administration. We discuss how we plan to high. We will revive the implementation of the original Kufuor policy of free maternal healthcare and free periodic maintenance programs we started during the Kufuor regime to improve road network conditions of the Single Spine Salary Structure initiated by the Kufuor administration to ensure fairness and equity The Culture Policy, developed and adopted under the Kufuor government, will be reviewed and actively the National Volunteer Service Programme in the Kufuor led NPP government. We will continue with of the University of Ghana stadium started by the Kufuor-led NPP government e. pursuing the vision of development. We will build on the achievement of the Kufuor Government and continue to build stadia in fertilizer distribution system that existed during the Kufuor administration and streamline the fertiliser on the far-reaching social intervention policies of the Kufuor-led NPP administration, such as the National UN PEACEKEEPING MISSION The NPP, under President Kufuor, in keeping with our tradition of enhancing It was for instance, the NPP government of President Kufuor that instituted a new realignment of salaries comprehensive Sports Bill initiated under President Kufuor b. ensuring that District Assemblies fully of the Municipal Finance Bill, initiated by the Kufuor-led NPP administration, into law. This law will Transport Policy that was put together during the Kufuor administration, and seeks to optimize our sector, com- tion Systems commenced during the Kufuor era and secure a sustainable titling people. Legislation and policies introduced under the Kufuor administration include providing free the National Volunteer Service Programme by the Kufuor-led NPP government. These were discovered in the Jubilee Fields as a result of the Kufuor-led NPP government's bold and farsighted , under the NPP government led by President J. A. Kufuor, moved from a highly indebted poor country . 1.1 THE PRESIDENCY The NPP through President Kufuor has brought back the dignity of the 23 purchase of vehicles by healthcare workers under the Kufuor-led NPP government $b$. strengthening 24 Scheme (NHIS). Under the leadership of President J.A. Kufuor, the NPP improved the health of Ghanaians by growth annually for the next four years (under the Kufuor-led NPP government the economy attained a GH $\phi 1.00(\phi 10,000)$ to GH $\$ .00(\phi 50,000)$. By the end of Kufuor's first term in 2004, it stood at GH 10.00

Figure 7: 26 of 36 concordance lines of Kufuor

Thus, one of the ways to debunk the rumours was to make Kufuor relevant in the 2008, 2012 and 2016 manifestos. The assumption is that if they were not on good terms, Kufuor's name would not be mentioned in such an important document as a manifesto. The manifesto was, therefore, used to achieve two purposes: to ride on the strengths of the Kufuor administration while debunking the allegations of unhealthy relationship between Kufuor and Akufo-Addo.

\section{Conclusion}

The study demonstrates that the NPP and the NDC try to distinguish themselves from each other on the basis of policy, character and achievements through acclaim and attack (Benoit, 1997: 208; 2006: 11-17; 2017: 7) and comparison (Kyerewaa-Owusu, 2017). It has been shown that while the NDC mostly concentrate on policy issues and their strongholds, the NPP focus on policy and character. This is contrary to a long-standing view in Ghana that the NPP is more policy focused than the NDC'. This validates the view that corpus methods can help to uncover non-obvious meanings that are hidden from naked-eye perusal (Partington et al., 2013). The NDC's concentration on policies may result from the fact that the NDC has been in power for more years than the NPP (16 years as against 10 years of the NPP). This is because incumbents normally concentrate more on policy while challengers focus more on character (Benoit, 2007; Druckman et al., 2009; Trent \& Friedenberg, 2008).

The literature on the functional theory of political campaign messages somehow suggests that personality attacks are a feature of spoken campaign discourse. However, this study shows that personality attacks are also a feature of written campaign discourse.

One question that needs answering is the extent to which the focus on policy and personality affects electoral outcomes. For instance, the NPP lost the 2012 election, a period within which they referenced Mahama only three times. There was little incentive in attacking Mahama on the failures of the then government. No wonder Mahama was jointly referred to as the Mills-Mahama government, as in (the three instances of Mahama reference in the 2012 NPP Manifesto):

i. This ineptitude on the part of the NDC Mi//s-Mahama government;

i i. What Ghanaians have witnessed, under the late President John E A Mil/s and Vice President John D. Mahama is a failed leadership.

\footnotetext{
${ }^{1}$ For a confirmation, or otherwise, of this claim, we may need to compare this with spoken text from campaign platforms, since the written and spoken texts may evince different strategies.
} 
i i i. What we have witnessed under the four years of the Mi/ls-Mahama administration is an unprecedented period of squandered opportunities under a weak, corrupt and incompetent leadership.

The implication is that Mahama at the time did not have credibility issues, as he could not directly be held responsible for the said socio-politico-economic failures. However, the NPP won the 2016 elections, when they referenced Mahama 59 times, more than five times as Akufo-Addo. Thus, one could say that the intense fixation on Mahama paid off. It could also be argued that a passionate concentration on oneself without proportionate attention on the opponent candidate may be detrimental. While the NPP mentioned Mahama only three times in the 2012 manifesto, they mentioned Akufo-Addo 19 times. Again, the NPP lost the 2008 elections, and Kufuor's name appeared only five (5) times in the manifesto. Kufuor appeared 11 times in the 2012 manifesto; the NPP lost the election. It then increased to 18 in 2016; the NPP won that election. One can, therefore, argue that the NPP successfully benefited from the strong attachment to Kufuor and his achievements. Consequently, it is possible to conclude that the ability to demonstrate a good rapport between Akufo-Addo and Kufuor paid off.

Our analysis and discussion indicate that the strategic use of negative portrayals of political opponents (and their policies) can be essential for electoral victory. Attack on a candidate or policy may be appropriate within specific periods (Trent \& Friendenberg, 2008: 86); after all, "parties compete with each other by accentuating their individual strength in specific policy issues" (Schröader, 2018: 708). In other words, whether it is policy or personality acclaim and/or attack, the most important consideration should be contextual relevance. While character did not appear to be relevant in the 1996, 2000, 2004 and 2012 manifestos, it appeared to be highly significant in the 2016 elections. For example, even though Kufuor won the 2000 elections, his name appeared only once in the NPP manifesto. Unlike Akufo-Addo, Kufuor did not have character issues to fight off, and he did not have to prove his character ideals to the electorate. Attack on Mahama in 2008 and 2012 appeared to be irrelevant, but highly incentivised in 2016. Thus, relevance determines which policy or character traits (or which aspects of policy and character) are appropriate for a specific political environment and can have the maximum impact on voter behaviour and voting patterns.

On the basis of the foregoing, I propose a relevance model of political campaign messaging. I put forward the following for consideration when deciding on political campaign messages, whether on policy or personal qualities:

i. Consider, define and gauge the political atmosphere and environment.

ii. What is the mood of the electorate? What are their concerns?

iii. Which policy initiatives are likely to respond to the concerns of the electorate?

iv. Could the incumbent government have done something about such needs? If yes, why have they failed to do so? If no, is attacking the government on such basis justifiable enough to convince the electorate? Can you propose an alternative?

v. If it is the person, consider which character traits or issues are relevant within the current political context. This is relevant, considering that people's perceptions about character change over time. For example, while arrogance could be frowned upon years ago, it may not necessarily be disfavoured within the current political context.

Responses to these issues could determine whether or not to acclaim or attack certain policies and/or personal qualities of candidates. 


\section{References}

Ademilokun, M.A. (2015). Discursive strategies in selected political rally campaigns of 2011 elections in Southwestern Nigeria. International Journal of Society, Culture and Language, 3(1), 120-132.

Alqaseer, J. (2013). Political advertising in Kuwait: A functional discourse analysis (PhD thesis). University of South Carolina., United States.

Amegatcher, A.B.P. (2015). An Examination of television political advertising before the 2012 Presidential election (MA dissertation). University of Ghana, Legon, Ghana.

Ankrah, G.N.O. (2016). Why do politicians consistently attack each other? Retrieved from https://www.myjoyonline.com/politics/2016/october-24th/why-do-politicians-consistently-attack-each-other.php

Asamoah, K., Yeboah-Assiamah, E., \& Osei-Kojo, A. (2014). Journal of Social Science Studies, 1 (1), 44-56. Retrieved from http://dx.doi.org/10.5296/jsss.v1i1.4725

Ayee, J.R.A. (2011). Manifestos and elections in Ghana's fourth republic. South African Journal of International Affairs, 18(3), 367-384

Baker, P. (2006). The question is, how cruel is it? Keywords, foxhunting and the House of Commons, AHRC ICT methods network expert seminar on linguistics. Retrieved from www.methodsnetwork.ac.uk

Benoit, W.L. (1999). Seeing spots: A functional analysis of presidential television advertisements, 1952-1996. Westport, CT: Praeger Publishers.

Benoit, W.L. (2006). The functional theory of political campaign discourse. Proceedings of Ural State Pedagogical Linguistics, 18, 10-34.

Benoit, W.L. (2007). Communication in political campaign. New York: Peter Lang Publishing.

Benoit, W.L. (2011). A functional analysis of the 2011 English language Canadian Prime Minister debate. Contemporary Argumentation and Debate, 32, 45-69.

Benoit, W.L. (2017). Meta-analysis of research on the functional theory of political campaign discourse. Speaker \& Gavel, 54(1), 7-50.

Benoit, W.L., \& Henson, J.R. (2007). A functional analysis of the 2006 Canadian and 2007 Australian election debates. Argumentation and Advocacy, 44(1), 36-48.

Benoit, W., \& Sheafer, T. (2006). Functional theory and political discourse: Televised debates in Israel and the United States. J \& MC Quarterly, 83(2), 281-297.

Benoit, W.L., \& Benoit-Bryan, J.M. (2014). A functional analysis of UK debates in Northern Ireland, Scotland, and Wales. Western Journal of Communication, 78 (5), 653-667.

Benoit, W.L., \& Benoit-Bryan, J.M. (2015). A functional analysis of 2013 Australian Member of Parliament and Prime Minister debates. Studies in Media and Communication, 3(2), 1-8.

Bentil, S., \& Aidoo, G.A. (2018). The negative implication of adversarialism and politics of insult in Ghana: An overview. Developing Country Studies, 8(4), 7-13.

Bondi, M. (2010). Perspectives on keywords and Keyness. In M. Bondi, \& M. Scott (Eds.) Keyness in texts (pp.120). Amsterdam/Philadelphia: John Benjamins.

Chilton, P. (2004). Analyzing political discourse: Theory and practice. London: Routledge.

Choi, Y.S., \& Benoit, W.L. (2016). A functional analysis of French and South Korean political debates. Speaker \& Gavel, 46 (1). Retrieved from https://cornerstone.lib.mnsu.edu/speaker-gavel/vol46/iss 1/7

Druckman, J.N., Kifer, M.J., \& Parkin, M. (2009). Campaign communications in U.S. congressional elections. American Political Science Review, 102(3), 343-366. https://doi.org/10.1017/S0003055409990037

Dudek, P., \& Partacz, S. (2009). Functional theory of political discourse: Televised debates during the parliamentary campaign in 2007 in Poland. Central European Journal of Communication, 2 (2 (3)), 367379.

Eder, N., Marcelo, J., \& Wolfgang, C.M. (2017). Manifesto functions: how party candidates view and use their party's central policy document. Electoral Studies, 45, 75-87.

Ehineni, T. O. (2014). A critical discourse analysis of modals in Nigerian political manifestos. International Journal of Linguistics, 6 (3), 109. 
Fernandez-Vasquez, P. (2018). Voter discounting of party campaign manifestos: an analysis of mainstream and niche parties in Western Europe, 1971-2011. Party Politics XX(X): 1-13. DOI:10.1177/1354068818787352

Flentje, J-E., König, T., \& Moritz, M. (2017). Assessing the validity of the manifesto common space scores. Electoral studies, 47, 25-35.

Fordjour, N.K.O. (2015). The use of Facebook in the 2012 presidential campaigns: A content analysis of John Dramani Mahama and Nana Addo Danquah Akufo-Addo's official pages (MPhil thesis). University of Ghana, Legon, Ghana.

Gabrielatos, C., \& Baker, P. (2008). Fleeing, sneaking, flooding: a corpus analysis of discursive constructions of refugees and asylum seekers in the UK press 1996-2005. Journal of English Linguistics, 36(5), 5-38.

Gyampo, R.E.V., \& Debrah, E. (2013). The youth and party manifestos in Ghanaian politics: The case of the 2012 general elections. Journal of African Elections, 12(2), 96-114.

Hahn, D.F. (1998). Political communication rhetoric, government, and citizens. Pennsylvania: Strata Publishing. Heywood, A. (2002). Politics (2 ${ }^{\text {nd }}$ ed.). New York, US: Palgrave MacMillan.

Isotalus, P. (2009). Agreement and disagreement in focus: A cultural perspective on televised election debates.

In R. Wilkins \& P. Isotalus (Eds.) Speech culture in Finland(191-208). Lanham, LD: University Press of America.

Isotalus, P. (2011). Analysing presidential debates: functional theory and Finnish political communication culture. Nordicom Review, 32(1), 31-43.

Isotalus, P., \& Aarnio, E. (2005). Medioidun vaalikeskustelun malli' [A model for mediated election discussion]. Puhe ja kieli, 25, 155-170.

Isotalus, P. \& Aarnio, E. (2006). A model of televised election discussion: the Finnish multi-party system perspective. Javnost-The Public, 13, 61-71.

Kiage, P. (2015). The print media and the land reform debate in the Kenya 2013 presidential elections. Elections Kenya 758), 58-95.

Kyerewaa-Owusu, D.A.A. (2017). A critical discourse analysis of the 2016 manifestos of the National Democratic Congress (NDC) and the New Patriotic Party (NPP) (MPhil. thesis). University of Ghana.

Louw, W.E. (2000). Contextual prosodic theory: Bringing semantic prosodies to life. In C. Heffer \& H.

Sauntson (Eds.), Words in context. In honor of John Sinclair. Birmingham: ELR.

Mayer, W.G. (1996). In defense of negative campaigning. Political Science Quarterly, 111(3), 437-455.

McEnery, T., \& Hardie, A. (2012). Corpus linguistics: Method, theory and practice. Cambridge, UK: Cambridge University Press

Moloi, K. C., \& Bojabotseha, T. P. (2014). A critical discourse analysis of intertextuality and interdiscursivity in the African National Congress (ANC). Academic Journal of Interdisciplinary Studies, 3 (4), 417.

Mordy, J.T. (2014). Akufo-Addo: I enjoyed total support from Kufuor in 2008, 2012. Retrieved from https://www.myjoyonline.com/politics/2014/May-30th/akufokufuor-in-2008-2012.php

Narteym M., \& Yankson, F.E. (2014). A semantic investigation into the use of modal auxiliary verbs in the manifesto of a Ghanaian political party. International Journal of Humanities and Social Science, 4(3): 21-30

National Democratic Congress (NDC). (1992). Constitution of the National Democratic Congress (NDC).

Netswera, F.G. (2016). The rhetoric of political election manifestos: An analysis of the African National Congress local government elections manifestos between 1995 and 2011. Loyola Journal of Social Sciences, 30 (2), 247-266

Ninsin, K.A. (2006). Political parties and political participation in Ghana. Accra, Ghana: Konrad Adenauer Stiftung.

Ofori, E. (2017). The use of insults to challenge political authority: A critical discourse analysis, Language, Discourse \& Society, 5(1), 129-144.

Osam, E.I. (2014). Kufuor and I are on good terms Akufo-Addo. Retrieved from http://citifmonline.com/2014/05/30/kufuorand-i-are-on-good-terms-nana-addo/ 
Partington, A., Duguid, A. \& Taylor, C. (2013). Patterns and meaning in discourse: Theory and practice in corpusassisted discourse studies. Amsterdam: John Benjamin.

Sarfo-Kantankah, K. S. (2018). It's about people: Identifying the focus of parliamentary debates through a corpus driven approach. Corpora, $13(3)$ : 393-430.

Sarfo-Kantankah, K. S. (2019). Discursive construction of the representative claim in UK and Ghanaian parliamentary discourse. In S.G. Obeng and E. Debrah (eds.). Ghanaian Politics and Political Communication (pp.159-183). London/New York: Rowman and Littlefield International.

Scott, M. (1997). PC analysis of keywords - and key keywords. System, 25(2), 233-245.

Scott, M. (2001). Comparing corpora and identifying key words, collocations, and frequency distributions through the Wordsmith Tools suite of computer programs. In M. Ghadessy, A. Henry \& R.L. Roseberry, (Eds.), Small Corpus Studies and ELT(pp.47-67). Amsterdam: John Benjamins.

Trent, J.S., \& Friedenberg, R.V. (2008). Political campaign communication: Principles and practices. Rowman \& Littlefield.

Van Dijk, T.C. (1997). What is political discourse analysis? Belgian Journal of Linguistics, 11(1), 11-52. 